\title{
Effects of Foreign Direct Investment Inflows and Domestic Investment on Economic Growth: Evidence from Turkey
}

\author{
Yilmaz Bayar ${ }^{1}$ \\ ${ }^{1}$ Faculty of Business Administration, Karabuk University, Karabuk, Turkey \\ Correspondence: Y1lmaz Bayar, Faculty of Business Administration, Karabuk University, Karabuk, Turkey. Tel: \\ 90-370-433-8262. E-mail: yilmazbayar@karabuk.edu.tr
}

Received: December 28, 2013

Accepted: January 15, 2014

Online Published: March 25, 2014

doi:10.5539/ijef.v6n4p69

URL: http://dx.doi.org/10.5539/ijef.v6n4p69

\begin{abstract}
Foreign direct investment flows have increased worldwide over the past three decades in conjunction with financial globalization and thus many studies have been conducted to examine possible effects of foreign direct investment inflows on economic growth. This study investigates the relationship between economic growth and foreign direct investment inflows, domestic investment in Turkey during the period 1980-2012 by using co-integration test and vector error correction model based on autoregressive distributed lag bound test approach. We found that there was a long run relationship among the economic growth, foreign direct investment inflows and domestic investment. On the other hand our findings demonstrated that foreign direct investment inflows affected economic growth negatively in the short and long run, while gross domestic investments affected economic growth positively in the short and long run.
\end{abstract}

Keywords: foreign direct investment, domestic investment, economic growth

\section{Introduction}

Foreign direct investment (FDI) inflows increased US\$2.002 trillion in 2007 from US\$ 13.346 billion in 1970 in the world (UNCTAD, 2013a). The studies on the effect of FDI inflows on national economies also increased in parallel with the increasing FDI flows in the world. There has been an extensive literature on the effects of FDI inflows on a host country's domestic investment, financial development, trade, productivity, technological progress and economic growth. FDI inflows are expected to contribute to the economic growth by affecting national economies through transfer of technology and know-how, formation of labor force, enhancing enterprise development, contributing to global trade integration and helping create a more competitive business environment (OECD, 2002).

FDI inflows are expected to affect economic growth only in the short run according to the traditional neo-classical growth models. Because traditional neo-classical growth models propose that the economies would converge to its steady state with diminishing returns to capital inputs in the long run (De Mello, 1997). On the other hand endogenous growth models propose that governments can affect economic growth in the long run by economic policies. So in the context of endogenous growth models FDI inflows are expected to affect economic growth both in short and long run through transfer of technology and know-how, productivity spillovers, increasing and developing skilled labor and helping the creation more competitive business environment (De Mello, 1997). The extent to which FDI inflows enhance economic growth depends on the degree of complementary and substitution relationship between FDI inflows and domestic investment (DI) (De Mello, 1999).

Turkey belatedly attracted FDI inflows due to frequent financial crises and political instability in 1980s and 1990s. FDI inflows to Turkey began to increase with contribution of increasing privatization since 2001 when Turkey recovered from the 2001 crisis gradually and gained political stability. The objective of this study is to examine the effects of FDI inflows and DI on the economic growth during the period 1980-2012 in Turkey by using co-integration test based on autoregressive distributed lag model (ARDL) bound test approach.

The remainder of the paper is structured as follows. Section 2 presents major studies on the relationship between economic growth and FDI inflows, DI in the literature. Section 3 gives information about the data, method used in the study and Section 4 presents econometric application and its main empirical findings and Section 5 
concludes the study.

\section{Literature Review}

Many studies have been conducted on the relationship among FDI inflows, DI and economic growth in the literature. Most of the studies generally have focused on the relationship between economic growth and FDI inflows, some studies have focused on the relationship between DI and FDI inflows, some studies have concentrated on the relationship between economic growth, FDI inflows and DI. The studies which examined the relationship between economic growth and FDI inflows reached mixed findings. Most of the studies in the literature such as Mun et al. (2008), Heteş et al. (2009), Anwar and Nguyen (2010), Chang (2010), Tiwari and Mutascu (2011), Asghar and Nasreen (2011), Lean and Tan (2011) and Soumia and Abderrezzak (2013) found that FDI inflows have had a positive impact on economic growth, while relatively few studies such as Mencinger (2003) and Saqib et al. (2013) found that that FDI inflows have had a negative impact on economic growth. On the other hand Lyroudi et al. (2004), Mohamed et al. (2013) and Chowdhary and Kushwaha (2013) found that FDI inflows did not exhibit any significant relationship with economic growth.

The relationship between FDI inflows and DI is also controversial. Some studies such as Xu and Wang (2007), Tang et al. (2008), Chang (2010), Lean and Tan (2011), Mahmood and Chaudhary (2012) and Mohamed et al. (2013) found that FDI inflows have crowded in DI while some studies such as Adams (2009), Acar et al. (2012) and Pilbeam and Oboleviciute (2012) found that FDI inflows have crowded out DI. On the other hand Sağlam and Yalta (2011) and Chowdhary and Kushwaha (2013) found that there was no relationship between FDI inflows and DI. Some studies such as Agosin and Machado (2005) and Wang (2010) found that FDI inflows have had neutral, crowding-in effect and crowding-out effect on DI depending on country/country group.

There have been a limited number of studies that have examined the relationship between economic growth and FDI inflows, DI together. Choe (2003) investigated the relationship among the FDI inflows, DI and economic growth in 80 countries during the period 1971-1995 by using panel VAR model, found that there was a bidirectional causality between FDI inflows and economic growth, a unidirectional causality from economic growth to DI. Xu and Wang (2007) examined the effects of FDI inflows on China's DI, exports, imports, and GDP growth during the period 1980-1999. They found that there was a complementary relationship between FDI inflows and DI; FDI inflows also had a positive effect on economic growth. Bilgili et al. (2007) investigated the relationship between FDI inflows, DI and economic growth in Turkey during the period 1992-2004 by using VAR analysis. They found that there was bidirectional causality between DI and economic growth.

Tang et al. (2008) investigated the relationship between FDI inflows, DI and economic growth in China during the period 1988-2000 by using a multivariate VAR system and co-integration. They found that there was complementary relationship between FDI inflows and DI and there existed bidirectional causality between GDP and DI and a unidirectional causality from FDI inflows to DI and from FDI inflows to GDP and DI had a greater impact on growth than FDI inflows did. Almasaied et al. (2008) examined the relationship between FDI inflows, DI and economic growth in Association of Southeast Asian Nations (ASEAN) during the period 1968-2002 by using ARDL cointegration. They found that FDI inflows and DI had a positive significant effect on economic growth.

Elboiashi et al. (2009) examined the relationship between FDI inflows, DI and economic growth in Egypt, Morocco and Tunisia during the period 1970-2006 by using cointegration test and causality test. They found that FDI inflows had a short run negative effect and long run positive effect on both DI and economic growth. Additionally they found that there was a unidirectional causality between FDI inflows and economic growth in Egypt and Morocco and bidirectional causality between FDI inflows and economic growth in Tunisia and FDI inflows crowded in DI in the short term while FDI inflows crowded out DI in the short term. Adams (2009) examined the effect of FDI inflows and DI on economic growth in Sub-Saharan Africa during the period 19902003 by using panel analysis and found that DI was positive and significantly correlated with economic growth in both the OLS and fixed effects estimation, while FDI was positive and significant only in the OLS estimation and FDI inflows crowded out DI.

Chang (2010) examined the relationship among the FDI inflows, domestic capital and economic growth in Taiwan during the 1981-2008 by using threshold error-correction approach, found that there existed a unidirectional causality from economic growth to DI and from DI to FDI inflows and FDI inflows had a positive effect on economic growth and FDI inflows crowded in domestic investment. Ghazali (2010) investigated the relationship between FDI inflows, DI and economic growth in Pakistan during the 1981-2008 by using cointegration and causality test, found that there was a bidirectional causality between FDI inflows and DI; DI and economic growth; a unidirectional causality between FDI inflows and economic growth in the long term. 
Lean and Tan (2011) used Granger causality to examine the relationship between FDI inflows, DI and economic growth in Malaysia during the period 1970-2009 by using Johansen-Juselius cointegration test and Granger causality test. They found that FDI inflows had a positive impact on economic growth, while DI had a negative impact on economic growth in the long term and there existed a complementary relationship between FDI inflows and DI, in other words FDI inflows crowded in DI. They also reached the finding that there was a unidirectional causality from DI to FDI inflows and from economic growth to FDI inflows in the short term. Chakraborty and Mukherjee (2012) examined the relationship between FDI inflows, DI and economic growth in India by using cointegration and causality tests and they found that there was a unidirectional causality from economic growth to FDI inflows and from FDI inflows to DI.

Mohamed et al. (2013) examined the relationship between economic growth and FDI inflows, DI and also investigated the relationship between FDI inflows and DI in Malaysia during the period 1970-2008 by using vector error correction model, impulse response function and variance decomposition analysis. They found that there existed bidirectional causality between DI and economic growth and no causality between FDI inflows and economic growth in the long run while there existed a crowding-in effect between FDI inflows and DI in the short run. Sooreea-Bheemul and Sooreea (2013) investigated the relationship between FDI inflows, exports, DI and economic growth in 28 developing and emerging countries during the 1989-1998 period by using panel Granger causality tests. They found that there was a unidirectional causality from economic growth to DI and bidirectional causality between all other variable pairs. Chowdhary and Kushwaha (2013) used Granger causality to investigate the relationship among FDI inflows, DI and economic growth in India during the period 19922012 and they found that there was bidirectional causality between DI and economic growth and no causality between FDI inflows and economic growth; FDI inflows had no effect on DI.

\section{Data and Method and Empirical Findings}

\subsection{Data}

We used annual data of real gross domestic product (RGDP) growth, net FDI inflows as a percent of GDP and DI as a percent of GDP from 1980 to 2012 to investigate the relationship between economic growth and FDI inflows, DI. RGDP growth for Turkey was taken from the database of United Nations Conference on Trade and Development (UNCTAD)(UNCTAD, 2013b), while net FDI inflows and gross domestic investment for Turkey were taken from World Development Indicators of the World Bank (World Bank, 2013a; 2013b).

The variables used in the econometric analysis and their symbols are presented in Table 1. Eviews 7.1 statistical software package was used in the analysis of the dataset.

Table 1. Variables used in the econometric analysis and their symbols

\begin{tabular}{ll}
\hline Variable Symbols & Variables \\
\hline GDPGR & Real GDP Growth \\
FDI & Net FDI Inflows \\
DINV & Domestic Investments \\
\hline
\end{tabular}

\subsection{Method}

We examined the relationship among the RGDP growth, FDI inflows and DI in a time-series analysis. First, we conducted the stationarity tests of the series by Augmented Dickey-Fuller (1979) test (ADF) and Phillips-Perron (PP) (1988) test. We then analyzed the long and short run relationship among the variables by co-integration test based on ARDL bound test approach.

Engle-Granger (1987), Johansen (1988) and Johansen and Juselius (1990) tests are generally used for the co-integration test in the literature, but time series are required to be stationary at the same level in order to apply these tests. ARDL bound testing approach, which were developed by Pesaran and Shin (1995) and Pesaran et al. (2001), enables us to apply co-integration tests to the time series which have different integration levels. However VECM can be obtained by a simple linear transformation simultaneously in this approach. Also it is possible that there is no co-integration relationship if all data are $\mathrm{I}(1)$ when there is limited number of data in the analysis of time series. So ARDL bound testing approach become prominent. But since the critical values of Pesaran et al. (2001) were determined by considering that the variables are I $(0)$ or I(1), variables should be tested in the event that the variables are I(2). ARDL bounding test approach has better statistical properties than Engle-Granger co-integration test does, because the unconstrained error correction model is used in the ARDL 
bound testing approach and ARDL bounding test approach also provides more reliable results in small samples than Engle-Granger and Johansen co-integration tests do.

(1) numbered bound test model below with two independent variables based on the estimation of unconstrained error correction models by least-square method. (1) numbered equation includes lags difference of dependent and independent variables and one lag of independent variables. Each lag difference of dependent and independent variables point out short run dynamics and show the possible changes in the dependent variable, while ratio of each lag value coefficient to the coefficient of dependent variable shows the long run dynamics.

$$
\begin{gathered}
\Delta \ln G D P G R_{t}=\beta_{0}+\sum_{i=1}^{m} \beta_{1 i} \Delta \ln G D P G R_{t-i}+\sum_{i=0}^{m} \beta_{2 i} \Delta \ln F D I_{t-i}+\sum_{i=0}^{m} \beta_{3 i} \Delta \ln D I N V_{t-i}+\theta_{1} \ln G D P G R_{t-1}+ \\
\theta_{2} \ln F D I_{t-1}+\theta_{3} \ln D I N V_{t-1}
\end{gathered}
$$

Co-integration relationship is conducted by testing null hypothesis $H_{0}: \theta_{1}=\theta_{2}=\theta_{3}=0$ against alternative hypothesis $H_{A}: \theta_{1} \neq \theta_{2} \neq \theta_{3}$. Pesaran et al. (2001) gave critical values in their studies because the critical values of bound test are not consistent with standard $\mathrm{F}$ distribution. If $\mathrm{F}$ statistic is above upper critical value, there is co-integration relationship among the time series. On the other hand if $\mathrm{F}$ statistic is below the lower critical value, there is no co-integration relationship among the variables. Finally if $\mathrm{F}$ statistic is between upper and lower critical values, alternative co-integration tests such as Engle and Granger (1987), Johansen (1988) and Johansen and Juselius (1990) which consider the integration levels of time series should be used.

$\mathrm{m}$ (lag length) in the (1) numbered equation should firstly be determined while applying bound test. Information criteria are used in the determination of optimal lag lengths. We used Akaike Information Criterion (AIC) and Schwartz Criterion (SC) in determination of optimal lag lengths. Since there is autocorrelation in case of lags, there should be no autocorrelation among the error term series for the bound test to provide accurate results.

\section{Econometric Application and Empirical Findings}

\subsection{Stationarity Analysis}

We tested the stationarity of the variables with ADF and PP tests, because macroeconomic time series may not exhibit stationarity over time. The results of stationarity tests were presented in Table 2. We found that GDPGR was stationary at level, and FDI and DINV variables were stationary at the first level according to the ADF and PP statistics.

Table 2. Results of stationarity tests

\begin{tabular}{lllllll}
\hline & \multirow{2}{*}{ Level } & \multicolumn{1}{c}{ Model } & \multicolumn{2}{c}{ ADF } & \multicolumn{2}{c}{ PP } \\
\cline { 3 - 6 } & & & t-Statistic & Prob.* & Adj. t-Stat & Prob.* \\
\hline \multirow{2}{*}{ GDPGR } & Level & Constant & -6.579151 & 0.0000 & -8.049254 & 0.0000 \\
& Level & Constant + Trend & -6.457590 & 0.0000 & -8.045403 & 0.0000 \\
& Level & Constant & -1.888403 & 0.3324 & -1.742930 & 0.4009 \\
& Level & Constant + Trend & -2.694554 & 0.2467 & -2.305594 & 0.4192 \\
& First Difference & Constant & -4.97743 & 0.0014 & -8.017233 & 0.0000 \\
& First Difference & Constant + Trend & -5.11377 & 0.0001 & -7.666041 & 0.0000 \\
DINV & Level & Constant & -2.757774 & 0.0758 & -2.708828 & 0.0836 \\
& Level & Constant + Trend & -2.699764 & 0.2433 & -2.642056 & 0.2656 \\
& First Difference & Constant & -7.166129 & 0.0000 & -7.279310 & 0.0000 \\
& First Difference & Constant + Trend & -7.056220 & 0.0000 & -7.252102 & 0.0000 \\
\hline
\end{tabular}

Note. *MacKinnon (1996) one-sided p-values.

\subsection{Co-integration Test Based on ARDL Bound Test Approach}

The variables had different integration levels as consequence of unit root tests. Therefore we applied $F$ test to the (1) numbered equation to investigate the long run relationship among the variables. The results of ARDL bound test and their critical values were presented in Table 3. The results demonstrated that there was a long run relationship among the variables. 
Table 3. Results of co-integration test based on ARDL bound test approach

\begin{tabular}{|c|c|c|c|c|c|c|}
\hline \multirow{2}{*}{$\begin{array}{l}\text { Independent } \\
\text { Variable }\end{array}$} & \multirow[b]{2}{*}{ Function } & \multirow[b]{2}{*}{ F-Statistics } & \multicolumn{4}{|c|}{ Diagnostic Test Results } \\
\hline & & & $\chi_{\text {NORMALL }}^{2}$ & $\chi_{A R C H}^{2}$ & $\chi_{R E S E T}^{2}$ & $\chi_{\text {SERIAL }}^{2}$ \\
\hline $\ln G D P$ & $F(\ln G D P \mid \ln F D I, \ln D I)$, & 9.1134 & 0.341 & [1]:1.099 & {$[1]: 0.885$} & [2]:1.239 \\
\hline \multicolumn{7}{|c|}{ Asymptotic Critical Values } \\
\hline & \multicolumn{2}{|l|}{$1 \%$} & \multicolumn{2}{|c|}{$5 \%$} & \multicolumn{2}{|c|}{$10 \%$} \\
\hline & $\mathrm{I}(0)$ & (1) & $\mathrm{I}(0)$ & $\mathrm{I}(1)$ & $\mathrm{I}(0)$ & $\mathrm{I}(1)$ \\
\hline Narayan (2005) & 3.436 & 667 & 2.921 & 4.946 & 2.935 & 3.623 \\
\hline
\end{tabular}

Note. Critical values were taken from Case III table in according to Narayan (2005) (k (number of independent variables) $=3$ and (number of observations) $=33$ ).

AIC and SC criteria were used in the determination of optimum lag length of ARDL model and the estimation was made by taking maximum lag length as 8 . ARDL $(1,1,1)$ model was selected as a common consequence of both criterion. The long run coefficients of ARDL $(1,1,1)$ were presented in Table 4 . The coefficients of the variables were found to be statistically significant as seen from Table 4 . The results demonstrated that there was a long run relationship among the variables and FDI inflows had negative impact on economic growth, while gross domestic investments had positive impact on economic growth. Also empirical findings demonstrated that $1 \%$ increase in FDI inflows led a $0.33 \%$ decrease in the economic growth, while $1 \%$ increase in gross domestic investments caused a $0.30 \%$ increase in economic growth in according to our model.

Table 4. Long-run coefficients of ARDL $(1,1,1)$ model

\begin{tabular}{|c|c|c|c|c|}
\hline Variables & Coefficient & Std. Error & t-statistics & p-value \\
\hline \multicolumn{5}{|c|}{ Dependent Variable: InGDPGR } \\
\hline $\operatorname{lnGDPGR}(-1)$ & -0.848299 & 0.407542 & -2.081500 & 0.0374 \\
\hline $\operatorname{lnFDI}$ & -0.368689 & 0.091292 & -4.038574 & 0.0003 \\
\hline $\operatorname{LnFDI}(-1)$ & -0.333506 & 0.119799 & -2.783881 & 0.0054 \\
\hline $\operatorname{lnDINV}$ & 0.393320 & 0.068419 & 5.748724 & 0.0000 \\
\hline $\operatorname{LnDINV(-1)}$ & 0.305337 & 0.089373 & 3.416436 & 0.0016 \\
\hline $\mathrm{C}$ & 8.637991 & 3.998119 & 2.160514 & 0.0373 \\
\hline \multicolumn{5}{|c|}{ Long run coefficients } \\
\hline Variable & Variable & Std. Error & \multicolumn{2}{|c|}{ t-statistics } \\
\hline $\operatorname{lnGDP}$ & 0.868772 & 0.053168 & \multicolumn{2}{|c|}{16.34027} \\
\hline $\operatorname{lnFDI}$ & -0.336092 & 0.143964 & \multicolumn{2}{|c|}{-2.334559} \\
\hline $\operatorname{lnDI}$ & 0.350854 & 0.053698 & \multicolumn{2}{|c|}{6.533783} \\
\hline $\mathrm{C}$ & 6.839451 & 0.695640 & \multicolumn{2}{|c|}{9.831878} \\
\hline \multicolumn{5}{|c|}{ Long Run Diagnostic Test Results } \\
\hline & \multicolumn{2}{|l|}{ F-test statistics } & \multicolumn{2}{|l|}{ p-value } \\
\hline$\chi_{\text {SERIAL }}^{2}$ & \multicolumn{2}{|l|}{1.4377} & \multicolumn{2}{|l|}{0.281} \\
\hline$\chi_{R A N B E Y}^{2}$ & \multicolumn{2}{|l|}{1.155} & \multicolumn{2}{|l|}{0.272} \\
\hline$\chi_{\text {NORMAL }}^{2}$ & \multicolumn{2}{|l|}{1.106} & \multicolumn{2}{|l|}{0.157} \\
\hline$\chi_{\text {WHITE }}^{2}$ & \multicolumn{2}{|l|}{1.569} & \multicolumn{2}{|l|}{0.102} \\
\hline$\chi_{A R C H}^{2}$ & \multicolumn{2}{|l|}{1.872} & \multicolumn{2}{|l|}{0.157} \\
\hline
\end{tabular}

Note. $\mathrm{R}^{2}=0.759$; Adjusted $\mathrm{R}^{2}=0.742$ Durbin Watson=2.23 F-statistics $=89.068(0.000)$.

Moreover we used cumulative sum (CUSUM) test of structural break for the long run relationship equation and we found that there were no structural breaks as seen in Figure 1. 




Figure 1. Structural break test of long run relationship equation

\subsection{Vector Error Correction Model}

The short run relationship among the variables in our study was analyzed error correction model based on ARDL bound test approach. The short run coefficients of ARDL $(1,1,1)$ model were presented in Table 5 . The empirical findings demonstrated that there was short run relationship among the variables. FDI inflows had negative effect on economic growth in the short run, while gross domestic investments had positive effect on economic growth in the short run. The statistically significant negative coefficient of ECT(-1) verified the long run relationship among the variables. Moreover error correction term measures how quickly the endogenous variable adjusts to the changes in the independent variables before the endogenous variable converges to the equilibrium level. Negative and statistically significant error correction term demonstrates that adjustment process is effective in restoring equilibrium. Negative but low error correction term in absolute value points out a slow adjustment. ECT term of our model was found to be statistically significant and -0.693 . This finding demonstrated that $69 \%$ of a deviation $t_{-1}$ period will be adjusted in t period. So our independent variables did not have a significant impact on the economic growth in the short run. A $1 \%$ increase in FDI inflows caused a $47 \%$ decrease in economic growth in the short run, while a $1 \%$ increase in gross domestic investments caused a $46 \%$ increase in the economic growth in the short run, in other other words response was found to be more in the short run than the one in the long run.

Table 5. VECM results

\begin{tabular}{lcccc}
\hline Variables & Coefficient & Std. Error & t statistics & p- value \\
\hline Independent Variable: $\Delta$ lnGDPGR & & & \\
$\Delta \operatorname{lnGDP}(-1)$ & 0.761254 & 0.211961 & 3.591479 & 0.0005 \\
$\Delta \operatorname{lnFDI}$ & -0.439023 & 0.132419 & -3.315416 & 0.0014 \\
$\Delta \operatorname{lnFDI}(-1)$ & -0.567797 & 0.181855 & -3.122251 & 0.0026 \\
$\Delta \operatorname{lnDI}$ & 0.508780 & 0.109359 & 4.652381 & 0.0000 \\
$\Delta \operatorname{lnDI}(-1)$ & 0.478747 & 0.149656 & 3.198973 & 0.0021 \\
ECT(-1) & -0.693475 & 0.290279 & -2.388998 & 0.0189 \\
$\mathrm{C}$ & 1.385706 & 0.325507 & 4.257073 & 0.0000 \\
\hline Short run coefficients & & & & \\
& Coefficient & Std. Error & $\mathrm{t}$ statistics. & \\
$\operatorname{lnGDP}$ & 0.780078 & 0.016787 & 46.46911 & \\
$\operatorname{lnFDI}$ & -0.478747 & 0.157227 & -3.044946 & \\
$\operatorname{lnDI}$ & 0.461820 & 0.155525 & 2.969424 & \\
$\mathrm{C}$ & 1.390730 & 0.256716 & 5.417388 & \\
\hline
\end{tabular}




\begin{tabular}{|c|c|c|c|}
\hline \multicolumn{4}{|c|}{ Short run diagnostic test results } \\
\hline & & F-test statistics & $\mathrm{p}$ value \\
\hline$\chi_{S E R I A L}^{2}$ & & 1.225 & 0.125 \\
\hline$\chi_{R A M S E Y}^{2}$ & & 1.763 & 0.167 \\
\hline$\chi_{\text {NORMAL }}^{2}$ & & 0.872 & 0.145 \\
\hline$\chi_{\text {WHITE }}^{2}$ & & 1.408 & 0.139 \\
\hline$\chi_{A R C H}^{2}$ & & 0.752 & 0.113 \\
\hline $\mathrm{R}^{2}=0.712$ & Adjusted $\mathrm{R}^{2}=0.68$ & Durbin Watson $=2.226$ & F statistics $=23.68$ \\
\hline
\end{tabular}

Moreover we used CUSUM test of structural break for the short run relationship equation and we found that there were no structural breaks as seen in Figure 2.

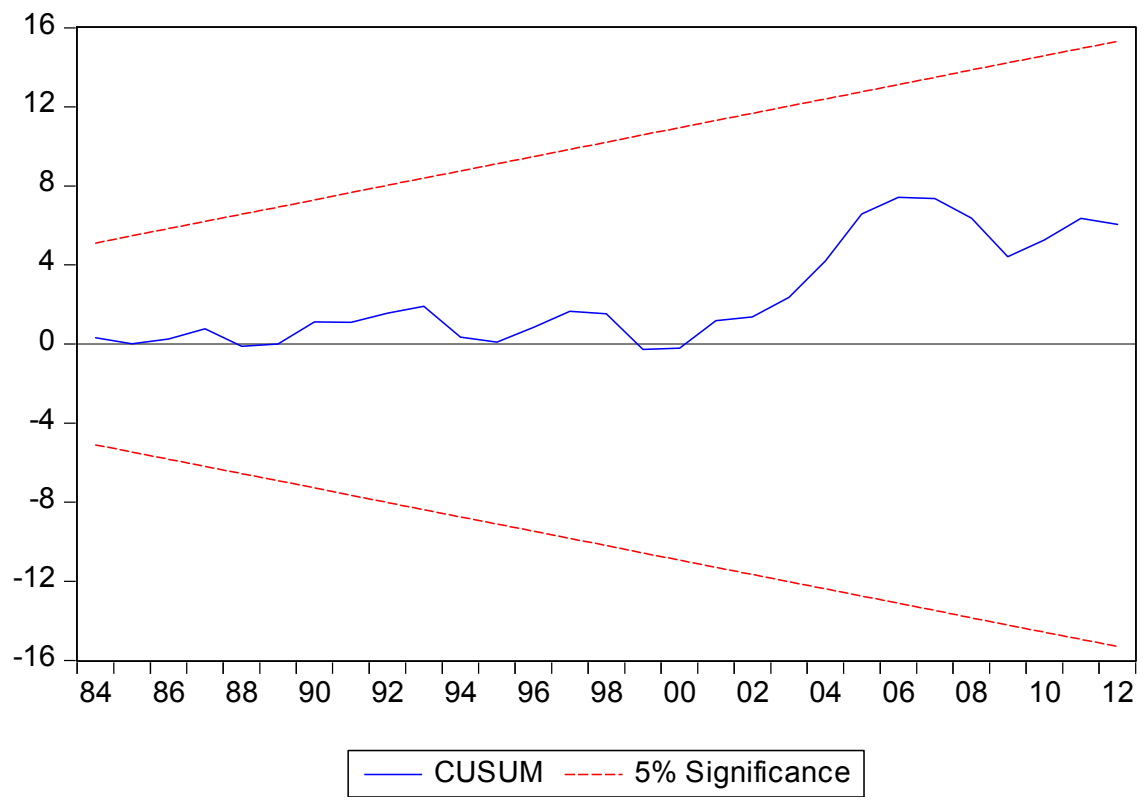

Figure 2. Structural break test of short run relationship equation

\section{Conclusion}

Many studies have been conducted to examine possible effects of foreign direct investment inflows and domestic investments on economic growth and these studies have reached mixed findings. Most of the studies in the literature found that FDI inflows and domestic investments have had a positive impact on economic growth, while relatively few studies found that FDI inflows have had a negative impact on economic growth. Again relatively few studies found that FDI inflows did not exhibit any significant relationship with economic growth.

This study investigated the effects of FDI inflows and domestic investments on the economic growth in Turkey during the period 1980-2012 by using co-integration test based on ARDL bound test approach. Our findings demonstrated that there was a long run relationship among the economic growth, FDI inflows and DI. The empirical findings demonstrated that FDI inflows had negative effect on economic growth, while gross domestic investments had positive impact on economic growth. Also empirical findings demonstrated that $1 \%$ increase in FDI inflows led a $0.33 \%$ decrease in the economic growth, while $1 \%$ increase in gross domestic investments caused a $0.30 \%$ increase in economic growth in according to our model. On the other hand VECM was found to be significant and the results showed that nearly $69 \%$ of the adjustments in the long run were realized in the short run.

Our findings demonstrated that FDI inflows affected economic growth negatively, while domestic investments affected economic growth positively. The negative relationship between economic growth and FDI inflows is 
consistent with the findings by Mencinger (2003) and Saqib et al. (2013), but not consistent with the general trend in the literature. The negative effect of FDI inflows on economic growth is is largely arisen from that most of the FDIs have flowed to the Turkey by privatization in form of of acquisition of fixed assets owned by public sector. Therefore Turkey should implement policies to attract FDI inflows in form of new investments to convert the negative effect of FDI inflows on economic growth to positive.

\section{References}

Acar, S., Eris, B., \& Tekce, M. (2012). The effect of foreign direct investment on domestic investment: Evidence from MENA countries. European Trade Study Group 14th Annual Conference, 13-15 September 2012, Leuven, Belgium.

Adams, S. (2009). Foreign direct investment, domestic investment, and economic growth in Sub-Saharan Africa. Journal of Policy Modeling, 31, 939-949. http://dx.doi.org/10.1016/j.jpolmod.2009.03.003

Agosin, M. R., \& Machado, R. (2005). Foreign investment in developing countries: Does it crowd in domestic investment? Oxford Development Studies, 33(2), 149-162. http://dx.doi.org/10.1080/13600810500137749

Almasaied, S. W., Baharumshah, A. Z., \& Rashid, S. (2008). The impact of domestic and foreign direct investments on economic growth: Evidence from ASEAN countries. Pertanika Journal of Social Sciences \& Humanities, 16(2), 239-255.

Anwar, S., \& Nguyen, L. P. (2010). Foreign direct investment and economic growth in Vietnam. Asia Pacific Business Review, 16(1-2), 183-202. http://dx.doi.org/10.1080/10438590802511031

Asghar, N., \& Nasreen, S. (2011). Relationship between FDI and economic growth in selected Asian countries: A panel data analysis. Review of Economics \& Finance, 84-96.

Bilgili, F., Düzgün, R., \& Uğurlu, E. (2007). Büyüme, doğrudan yabancı sermaye yatırımları ve yurtiçi yatırımlar arasındaki etkileşim. Erciyes Üniversitesi Sosyal Bilimler Enstitüsü Dergisi, 23, 127-151.

Chakraborty, D., \& Mukherjee, J. (2012). Is there any relationship between foreign direct investment, domestic investment and economic growth in India? A time series analysis. Review of Market Integration, 4(3), 309337. http://dx.doi.org/10.1177/0974929213481712

Chang, S. C. (2010). Estimating relationships among FDI inflow, domestic capital, and economic growth using the threshold error correction approach. Emerging Markets Finance \& Trade, 46(1), 6-15. http://dx.doi.org/10.2753/REE1540-496X460101

Choe, J. II (2003). Do foreign direct investment and gross domestic investment promote economic growth. Review of Development Economics, 7, 44-57. http://dx.doi.org/10.1111/1467-9361.00174

Chowdhary, R., \& Kushwaha, V. (2013). Domestic investment, foreign direct investment and economic growth in India since economic reforms. Journal of Transformative Entrepreneurship, 1(2), 74-82. http://dx.doi.org/10.14239/JTE.2013.01201

De Mello, L. R. (1997). Foreign direct investment in developing countries and growth: A selective survey. Journal of Development Studies, 34(1), 1-34. http://dx.doi.org/10.1080/00220389708422501

De Mello, L. R. (1999). Foreign direct investment-led growth: Evidence from time series and panel data. Oxford Economic Papers, 51(1), 133-151. http://dx.doi.org/10.1093/oep/51.1.133

Dickey, D. A., \& Fuller, W. A. (1979). Distribution of the estimators for autoregressive time series with a unit root. Journal of the American Statistical Association, 74, 427-431.

Elboiashi, H., Noorbakhsh, F., Paloni, A., \& Azemar, C. (2009). The casual relationships between foreign direct investment, domestic investment and economic growth in North African non-oil producing countries: Empirical evidence from cointegration analysis. Advances in Management, 2, 19-25.

Engle, R. F., \& Granger, C. W. J. (1987). Co-integration and error correction: Representation, estimation and testing. Econometrica, 55(1), 251-276.

Ghazali, A. (2010). Analyzing the relationship between foreign direct investment domestic investment and economic growth for Pakistan. International Research Journal of Finance and Economics, 47, 123-131.

Heteş, R., Moldovan, N., \& Miru, O. (2009). Foreign direct investments and economic growth in Central and Eastern European Countries. Megatrend Review, 6(2), 239-252.

Johansen, S. (1988). Statistical analysis of cointegration vectors. Journal of Economic Dynamics and Control, 12(2-3), 231-254. http://dx.doi.org/10.1016/0165-1889(88)90041-3. 
Johansen, S., \& Juselius, K. (1990). Maximum likelihood estimation and inference on cointegration-with applications to the demand for money. Oxford Bulletin of Economics and Statistics, 52, 169-210.

Lean, H. H., \& Tan, B. W. (2011). Linkages between foreign direct investment, domestic investment and economic growth in Malaysia. Journal of Economic Cooperation and Development, 32(4), 75-96.

Lyroudi, K., Papanastasiou, J., \& Vamvakidis, A. (2004). Foreign direct investment and economic growth in transition economies. South Eastern Europe Journal of Economics, 1, 97-110.

MacKinnon, J. G. (1996). Numerical distribution functions for unit root and cointegration tests. Journal of Applied Econometrics, 11, 601-618. http://dx.doi.org/10.1002/(SICI)1099-1255(199611)11:6<601::AID-JAE417>3.0.CO;2-T

Mahmood, H., \& Chaudhary, A. R. (2012). Foreign direct investment-domestic investment nexus in Pakistan. Middle-East Journal of Scientific Research, 11(11), 1500-1507.

Mencinger, J. (2003). Does foreign direct investment always enhance economic growth? Kilkos, 56(4), 491-508.

Mohamed, M. R., Singh, K. S. J., \& Liew, C. Y. (2013). Impact of foreign direct investment \& domestic investment on economic growth of Malaysia. Malaysian Journal of Economic Studies, 50(1), 21-35.

Mun, H. W., Lin, T. K., \& Man, Y. K. (2008). FDI and economic growth relationship: An empirical study on Malaysia. International Business Research, 1(2), 11-18.

OECD. (2002). Foreign direct investment for development: Maximising benefits, minimising costs. France: OECD Publications Service.

Pesaran, M. M., \& Shin, Y. (1995). Autoregressive distributed lag modelling approach to cointegration analysis. DAE Working Paper Series No.9514.

Pesaran, M. H., Shin, Y., \& Smith, R. (2001). Bounds testing approaches to the analysis of level relationships. Journal of Applied Econometrics, 16, 289-326.

Phillips, P. C. B., \& Perron, P. (1988). Testing for unit roots in time series regression. Biometrika, 75, 335-346. http://dx.doi.org/10.1093/biomet/75.2.335

Pilbeam, K., \& Oboleviciute, N. (2012). Does foreign direct investment crowd in or crowd out domestic investment? Evidence from the European Union. Journal of Economic Asymmetries, 9(1), 89-104.

Sağlam, B. B., \& Yalta, A. Y. (2011). Dynamic linkages among foreign direct investment, public investment and private investment: Evidence from Turkey. Applied Econometrics and International Development, 11(2), 71-82.

Saqib, N., Masnoon, M., \& Rafique, N. (2013). Impact of foreign direct investment on economic growth of Pakistan. Advances in Management \& Applied Economics, 3(1), 35-45.

Sooreea-Bheemul, B., \& Sooreea, R. (2013). Missing causality links between foreign direct investment, exports, domestic investment and economic growth. International Journal of Business and Emerging Markets, 5(4), 322-340. http://dx.doi.org/10.1504/IJBEM.2013.056713

Soumia, Z., \& Abderrezzak, B. (2013). The determinants of foreign direct investment and their impact on growth: Panel data analysis for AMU countries. International Journal of Innovation and Applied Studies, 2(3), 300313.

Tang, S., Selvanathan, E. A., \& Selvanathan, S. (2008). Foreign direct investment, domestic investment and economic growth in China: A time series analysis. World Economy, 31(10), 1292-1309. http://dx.doi.org/10.1111/j.1467-9701.2008.01129.x

Tiwari, A. K., \& Mutascu, M. (2011). Economic growth and FDI in Asia: A panel-data approach. Economic Analysis \& Policy, 41(2), 173-187.

UNCTAD. (2013a). Foreign direct investment. Retrieved from http://unctadstat.unctad.org/ReportFolders/reportFolders.aspx?sRF_ActivePath=P,5,27\&sRF_Expanded=P5

UNCTAD. (2013b). Economic trends. $\quad$ Retrieved from http://unctadstat.unctad.org/ReportFolders/reportFolders.aspx

Wang, M. (2010). Foreign direct investment and domestic investment in the host country: Evidence from panel study. Applied Economics, 42(29), 3711-3721. http://dx.doi.org/10.1080/00036840802314580

World Bank. (2013a). Foreign direct investment, net inflows (\% of GDP). Retrieved from 
http://data.worldbank.org/indicator/BX.KLT.DINV.WD.GD.ZS

World Bank. (2013b). Gross capital formation (\% of GDP). Retrieved from http://data.worldbank.org/indicator/NE.GDI.TOTL.ZS

$\mathrm{Xu}, \mathrm{G} .$, \& Wang, R. (2007). The effect of foreign direct investment on domestic capital formation, trade, and economic growth in a transition economy: Evidence from China. Global Economy Journal, 7(2), 1-21. http://dx.doi.org/10.2202/1524-5861.1198

\section{Copyrights}

Copyright for this article is retained by the author(s), with first publication rights granted to the journal.

This is an open-access article distributed under the terms and conditions of the Creative Commons Attribution license (http://creativecommons.org/licenses/by/3.0/). 